\title{
Justice, Well-Being, and Civic Duty in the Age of a Pandemic: Why we all Need to Do our bit
}

\author{
Johan C. Bester (D)
}

Received: 22 May 2020 / Accepted: 21 September 2020

(C) Journal of Bioethical Inquiry Pty Ltd. 2020

\begin{abstract}
This article presents an argument related to justice obligations during a pandemic and explores implications of the argument. A just society responds to a serious threat to the well-being of its people such as a viral pandemic to mitigate the impact of the pandemic on the well-being of its members. This creates identifiable societal obligations which are discharged by the institutions and individuals within society that are situated to do so. There are therefore identifiable obligations resting on various societal institutions, such as government, churches, schools, and corporate institutions, as well as obligations resting on individuals. Should an institution or individual fail to act in ways consistent with these social obligations, they perpetrate an injustice on society and its members.
\end{abstract}

Keywords Justice $\cdot$ Social justice $\cdot$ Well-being .

COVID-19 $\cdot$ Public health ethics

In this article I defend the following argument. A just society protects the well-being of its members. A pandemic such as COVID-19 threatens the well-being of people in unique and serious ways. This means that society has a justice obligation to respond to the pandemic and to protect the well-being of people against its impact. Society's obligations rest on those institutions

\section{J. C. Bester $(\bowtie)$}

UNLV School of Medicine, University of Nevada, Las Vegas, 2040 W Charleston Blvd, 4th Floor, Las Vegas, Nevada, USA e-mail: johan.bester@unlv.edu and individuals within society that are appropriately placed to discharge these obligations. A threat like the pandemic is so large and consequential that it takes collective action on a societal scale to combat and overcome it. This places obligations on all institutions and individuals within society to respond to the pandemic.

This argument has profound implications: everyone within society has identifiable obligations to minimize the impact of the pandemic. We all have to do our bit, every institution and every individual in society. In what follows, I will ground the premises upon which this argument depends. I will then touch on some identifiable obligations resting on individuals and institutions to respond to threats such as the pandemic.

\section{A Just Society Protects the Well-Being of its Members}

This premise can most straightforwardly be grounded by appeal to a theory of justice that connects justice to well-being, such as the justice theory of Powers and Faden (2006). According to this theory, a just society ensures for its members a minimum level of well-being as measured across six different dimensions: health, self-determination, security, reasoning, respect, and attachment. A life devoid of any of these components is not flourishing. Each of these components seem necessary to any conception of the good; they are things that everyone is presumed to want, whatever else they want. On this theory, society is to establish the kind of social 
environment that would allow people to reach a sufficient amount of well-being as measured by the six dimensions. Society is also to monitor and react to threats to well-being, things that may cause people to fall below sufficient levels on any of the dimensions. The theory shares much in common with another prominent contemporary justice theory, the capabilities approach of Nussbaum and Sen, which would lead to similar conclusions about the just society protecting the capabilities needed to achieve well-being (Nussbaum 2003; Nussbaum 2011; Sen 1985).

These related justice theories provide more than adequate grounding for the premise as it is stated. But I should note that this premise can also be grounded by reference to other prominent theories of justice, so that this premise would stand even if you are persuaded by a different theory of justice.

Take Rawls' theory of justice (Rawls 1971). Rawls puts forward a conception of justice that is egalitarian: the goods of life should be equally distributed, and unequal distributions can only be seen as just if it works to the advantage of the least well-off in society. The goods of life refer to those things that are neutral between conceptions of the good, that everyone is presumed to need. There is an overt focus on how well someone is doing: the least well-off in society form a benchmark for the fairness of the distribution of the goods of life. This clearly places the focus on flourishing or well-being. If there is a way to improve the wellbeing of the worst-off, justice demands that society do so. Daniels examines the implications of Rawls' theory for health, arguing that healthcare has special moral importance from the perspective of justice (Daniels 1985; Daniels 2007). Rawls' theory is concerned with equality of opportunity to access the goods of life. Healthcare protects and promotes the health of people, thereby promoting fair access to opportunities for individuals. It is therefore straightforward to see that a just society is concerned with well-being, and that when the worst-off can be made better-off, society has a justice obligation to intervene.

A strict libertarian theory of justice is concerned with the maximum freedom for individuals that can also be compatible with the same freedom for everyone else (Nozick 1974; Sandel 2009). The focus of the theory is on individual liberty, with defined liberty-limiting principles meant to safeguard overall liberty. Libertarians typically are in favour of limited government and frown on paternalism. But even here, one can see arguments that a just society protects the well-being of its members. First, consider the harm principle, a libertylimiting principle articulated by Mill. The actions and choices of individuals and actions of institutions that make up the social fabric are not permissible when such actions lead to harm to others, and society should intervene to prevent such harm. Harm refers to a setback to interests, which is to negatively affect someone's wellbeing. Thus, society is attentive to the well-being of its members, and has obligations to act against actions or components of the social fabric that set back the wellbeing of its members. Second, consider the ways in which well-being is needed to ensure liberty. If someone's well-being is negatively impacted, it restricts their options severely. The dead, the sick, those suffering under the effects of a pandemic - they are not free. They can't decide what to do with their lives or pursue the good as they see it. They are consumed by the restrictions placed on them by illness and by getting through the suffering of the pandemic. Well-being, it turns out, is a necessary platform that acts as springboard for liberty. A society that sees liberty as the focus of justice should also be concerned with promoting the well-being that enables liberty in the first place.

We are on safe ground if we say that a just society protects the well-being of its members. The implication is that society has justice obligations to institute protections for the well-being of its members and to respond to threats to well-being.

\section{A Pandemic Such as COVID-19 Threatens the Well-Being of People}

COVID-19 is a highly contagious infectious disease with serious complications and significant impact on life and health (CDC COVID-19 Response Team 2020; Liu Y et al. 2020a and b; Xu et al. 2020). At the time of writing, there have been over 1.9 million cases and over 110,000 COVID-19 deaths in the United States (CDC 2020). Worldwide, there have been over seven million cases and over 400,000 deaths (Worldometer 2020). The deaths in the United States are an example of the rapidity with which COVID inflicts mass casualties: the first known COVID cases were reported in January and February, and by June the death toll had reached over 100,000 .

COVID also threatens health in a way that can undermine well-being, sometimes even permanently. 
People who have survived ICU treatment will take months or years to recover, if they ever recover fully. While serious disease appears to be more likely in older people and those with underlying medical conditions, otherwise healthy younger people and children can develop severe disease and require hospitalization (CDC COVID-19 Response Team 2020; Liu K et al. 2020a and b; Oxley et al. 2020; Riphagen et al. 2020). These are early days, and the full impact of the disease is not yet fully understood. I would suggest that the complications from COVID that result in long-term ill health will only be fully realized going forward; right now, the focus is on the frightening ability COVID has to kill.

A pandemic of this nature also impacts other aspects of well-being. People naturally avoid settings where they can get infected, meaning that many aspects of normal social interaction shut down. Entertainment venues, places of worship, places where people buy and sell- every sector that makes society run socially and economically is impacted. People's income and work is affected. The ability to interact with others and form or maintain attachments are affected. Ultimately, liberty and self-determination also become affected as people become constrained by fear of disease, loss of functioning, and fraying of the social fabric. These would result from natural behaviour to avoid getting sick but would also follow from social distancing practices meant to minimize the pandemic. While the latter forms an important response to the pandemic, society must be aware of these impacts on well-being and respond to them appropriately. The solution is to mitigate the pandemic quickly.

\section{Society's Obligations Rest on Those Who Are Appropriately Placed to Discharge These Obligations}

Society consists of a complex fabric of individuals and institutions. Justice speaks to the organization and fabric of society, placing obligations on society to be and act a certain way. This creates societal obligations resting on the institutions and individuals within society that are set up to do so. Institutions may include government, clubs, business, religious organizations, and organized civic society. Individuals may refer to specific individuals who occupy important social roles, such as parents, teachers, doctors, nurses, law enforcement, and the like, or may refer to members of society writ large. There is no other way for society to discharge its obligations than by the actions of institutions and individuals who are placed in positions to act upon these obligations. Some issues that fall under the purview of justice require an overall societal response, placing obligations on virtually all institutions and individuals in society.

Let us consider this by reference to the example of racism. ${ }^{1}$ Racism subjugates the well-being of an entire group of people because of unjust discrimination. Racist discrimination could decrease access to jobs and income, educational opportunities, and healthcare, and ultimately decrease the scope for self-determination. To protect well-being against racism requires cooperation from society's institutions and members. Government should enforce policy and regulations that prohibit racism. Business should act in ways that remove racist discrimination from business practices. Healthcare systems and educational systems should ensure fair access for those who have been excluded due to racism. Individual people are obligated to refrain from racist discrimination, treat each other with respect, and support societal policies and actions that stamp out racism. To deal with an affront to justice like racism takes the collective effort of all of society. It is not just a problem for government to address; it is no good for government to set a policy against racism if many people in society continue to discriminate based on race or if businesses find creative ways around anti-racism laws. To achieve justice, those on whom society's obligations rest should work together. ${ }^{2}$

Ultimately, the lines between institutions and individuals blur-institutions are made up of individuals, and actions and decisions by individual people or groups of people fashion and shape the societal structure. A just society results from just actions by society's members and society's institutions in response to the moral claims placed on them by justice.

\footnotetext{
${ }^{1}$ In a similar vein, Powers and Faden present arguments about how the dimension of wellbeing called respect place obligations on various components of society (Powers and Faden 2006, 22-24, 89-90, 191193).

${ }^{2}$ I've argued a similar point elsewhere, defending a similar premise that society's obligations rest on those individuals and institutions that are so placed to discharge these obligations (Bester 2018). In that paper, I examined the distribution of vaccination obligations within a just society given the focus of justice as well-being. There I concluded that measles vaccination is owed to children and that the obligation to vaccinate rests on identifiable institutions and individuals within society.
} 
The Pandemic is so Large and Consequential a Threat That it Takes Collective Action on a Societal Scale to Combat and Overcome its Effect on Well-Being

The usual strategy to combat infectious disease outbreaks makes use of a combination of epidemiological tools (WHO 2014). This includes diagnosing cases and contacts, isolating cases and contacts, using vaccines or other forms of prevention, and providing available treatments. Efforts such as these have successfully limited measles outbreaks and Ebola outbreaks and were used to contain airborne viral pandemics such as H1N1 flu and SARS (Musa et al. 2015; Svoboda et al. 2004; WHO 2009; WHO 2014).

With the COVID-19 pandemic, a number of factors made it impossible to follow this strategy. There are specific variables of COVID disease that pose challenges to usual containment methods. For instance, the virus can be spread by asymptomatic individuals, which complicates case identification, and no vaccine or effective treatment exists (He 2020; Parodi and Liu 2020). But importantly, the initial response in some countries (for example, the United States) also meant that the usual methods of containment were not employed early enough to have any hope of their being successful (Abutaleb et al. 2020; Beggin 2020; Ray 2020; Shear et al. 2020; Sommer 2020). Testing was delayed and inadequate. Communication of preventive actions such as washing of hands and wearing of masks was delayed. When the threat was eventually acknowledged, it was already too late to prevent spread.

The only alternative is to practice wide-scale quarantine of sorts, or as it has become known, social distancing (Kenyon 2020; Rotondi et al. 2020; Thunstrom et al. 2020). Various states and countries enforced closing of business and schools and social distancing measures. The idea is that we stretch out the pandemic over a longer period, so-called "flattening the curve" so that the medical system would not be overwhelmed with cases. In so doing, the amount of complications and deaths from the pandemic is mitigated. Time is bought to develop vaccines, treatments, and a focused testing strategy. If these efforts are successful, the response can transition to the first strategy mentioned.

We know that such social distancing measures work. Studies show that social distancing measures have averted tens of millions of cases and saved millions of lives across a number of different countries (Hsiang et al. 2020; Flaxman et al. 2020). Part of the problem is that this response has implications in other aspects of society: economic downturns, implications for human relationships and social activities, and an impact on mental health of individuals, just to name a few. These can impact the well-being of people; if you lose your income and suffer loss in your relationships, your wellbeing is profoundly impacted.

Ideally, we would limit a threat from something like a pandemic with a focused public health response that allows the rest of society to continue as normal. If that is not possible, as in the current situation with COVID, and large-scale social distancing is needed, it becomes apparent that virtually all of society's cooperation to mitigate the pandemic is required. These considerations place obligations on identifiable institutions and almost all individuals. I will elaborate on this more in the next section.

\section{Implications of the Argument}

(1) We all need to do our bit.

With a pandemic such as COVID-19, justice requires a coordinated and far-ranging response from all of society. This means we all need to do our bit, every one of us, if we are to do what is right in the age of a pandemic.

First, we must consider what needs to be done to minimize spread and the impact on the health of people. Government must play a leading and coordinating role given the scope of the response required. Business and academia combine to create and evaluate tests, vaccines, and treatments. Public health officials, healthcare professionals, and healthcare institutions collaborate on testing, tracing, and treatment. Individual members of society also have their roles to play; vaccine uptake and the success of preventive measures depend directly on the cooperation of members of society. For social distancing and quarantine to work, large scale cooperation from people is required. Governments can mandate such measures, but it takes the willingness and cooperation of people to make it work. It takes only a few to eschew masks or to refuse to social distance to maintain disease spread.

These measures are essential, but society should also respond to the economic and social impacts of the pandemic on well-being. Government takes the lead in mitigating these impacts from the pandemic through 
coordination and policy. The corporate sector, churches, clubs, schools: we all need to make sure we mitigate the pandemic but also the fallout around the pandemic. Arrange for ways in which people can connect while social distancing. Maintain jobs, supply lines, infrastructure as much as is possible in a way that is compatible with preventing the spread of disease. No longer can the first priority of commerce be to make profit at any cost. The corporate sector, just as much a part of society as anyone else, has obligations to make sure that the wellbeing of members of society are protected. Individuals also have their bit to do. Comply with and encourage preventive measures to limit spread. Don't buy or take more than your share when you go shopping. Check in with neighbours, family members, friends while doing your bit to prevent spread. If you are able to, give and support where others suffer lack.

(2) Failing to act is immoral.

The pandemic places obligations on all of us. To fail to discharge these obligations is immoral; it perpetrates an injustice on society and on the members of society.

For example, governments that spread misinformation related to the pandemic and fail to coordinate testing and contact tracing that would limit disease act in ways that are unjust and unjustifiable. A religious group that continues to hold large church gatherings when it is known that such gatherings create prime conditions to spread disease flouts the responsibilities of the institution to society. People who refuse to perform preventive actions, such as not washing hands, not masking, and not socially distancing, risk spreading disease and act unjustly towards others. Actions of these kinds by institutions and individuals maintain the spread of disease, decrease the capacity of healthcare institutions to deal with those who are sick, and leads ultimately to more deaths and disease complications than would otherwise be the case. This translates into unnecessary deaths and preventable suffering. And such deaths and such suffering are profoundly unjust.

\section{Conclusion}

In this paper I've argued that justice requires society to respond to a viral pandemic, to protect the well-being of the members of society against the impact of the pandemic. This places identifiable obligations on the members and institutions of society. If we are to have a just society, everyone must do the work that justice requires in response to threats like the pandemic. If we fail to do so, we perpetrate an injustice on each other.

\section{References}

Abutaleb, Y., J. Dawsey, G. Miller, and E. Nakashima. 2020. Denial, dysfunction plagued U.S. government as coronavirus raged. Washington Post, April 6. https://www. washingtonpost.com/national-security/2020/04/04 /coronavirus-government-dysfunction/?arc404=true.

Beggin, R. 2020. Report: The CDC contaminated its first coronavirus tests, setting US back on testing. Vox, April 18. https://www.vox.com/2020/4/18/21226372/coronavirustests-cdc-contaminated-delay-testing.

Bester, J.C. 2018. Not a matter of parental choice but of social justice obligation: Children are owed measles vaccination. Bioethics 32(9): 611-619.

CDC COVID-19 Response Team. 2020. Severe outcomes among patients with coronavirus disease 2019 (COVID-19)United States, February 12-March 16. Morbidity and Mortality Weekly Report 69(12): 343-346.

Centers for Disease Control and Prevention (CDC). 2020. Coronavirus disease 2019: Cases in the U.S. https://www. cdc.gov/coronavirus/2019-ncov/cases-updates/cases-in-us. html. Accessed June 9, 2020.

Daniels, N. 1985. Just health care. New York: Cambridge University Press.

Daniels, N. 2007. Just health: Meeting health needs fairly. New York: Cambridge University Press.

Flaxman, S., S. Mishra, A. Gandy, et al. 2020. Estimating the effects of non-pharmaceutical interventions on COVID-19 in Europe. Nature 584: 257-261.

He, Z. 2020. What further should be done to control COVID-19 outbreaks in addition to cases isolation and contact tracing measures? BMC Medicine 18: 80.

Hsiang, S., D. Allen, S. Annan-Phan, et al. 2020. The effect of large-scale anti-contagion policies on the COVID-19 pandemic. Nature 584: 262-267.

Kenyon, C. 2020. Flattening-the-curve associated with reduced COVID-19 case fatality rates - An ecological analysis of 65 countries. Journal of Infection 18(1): e98-e99.

Liu, K., Y. Chen, R. Lin, and K. Han. 2020a. Clinical features of COVID-19 in elderly patients: A comparison with young and middle-aged patients. Journal of Infection 80(6): e14-e18.

Liu, Y., A. Gayle, A. Wilder-Smith, and J. Rocklov. 2020b. The reproductive number of COVID-19 is higher compared to SARS coronavirus. Journal of Travel Medicine 27(2).

Musa, E., E. Adedire, O. Adeoye, et al. 2015. Epidemiological profile of the Ebola virus disease outbreak in Nigeria, JulySeptember 2014. The Pan African Medical Journal 21: 331.

Nozick, R. 1974. Anarchy, state, and utopia. New York: Basic Books.

Nussbaum, M. 2003. Capabilities as fundamental entitlements: Sen and social justice. Feminist Economics 9(2-3): 33-59. 
Nussbaum, M. 2011. Creating capabilities: The human development approach. Cambridge, MA: Harvard University Press.

Oxley, T., J. Mocco, S. Majidi, et al. 2020. Large-vessel stroke as a presenting feature of COVID-19 in the young. The New England Journal of Medicine 382(1): 60.

Parodi, S., and V. Liu. 2020. From containment to mitigation of COVID-19 in the U.S. Journal of the American Medical Association 323(15): 1441-1442.

Powers, M., and R. Faden. 2006. Social justice. New York: Oxford University Press.

Rawls, J. 1971. A theory of justice. Cambridge, MA: Harvard University Press.

Ray, T. 2020. COVID-19 testing delays shine light on labdeveloped test regulation debate. Modern Healthcare, March 17. https://www.modernhealthcare.com/politicspolicy/covid-19-testing-delays-shine-light-lab-developedtest-regulation-debate.

Riphagen, S., X. Gomez, C. Gonzalez-Martinez, N. Wilkinson, and P. Theocharis. 2020. Hyperinflammatory shock in children during COVID-19 pandemic. The Lancet 395(10237): $1607-1608$.

Rotondi, V., L. Andriano, J.B. Dowd, and M. Mills. 2020. Early evidence that social distancing and public health interventions flatten the COVID-19 curve in Italy. OSF Preprints, April 26. doi:10.31219/osf.io/wah4e.

Sandel, M. 2009. Justice. What is the right thing to do? New York: Farrar, Straus and Giroux.

Sen, A. 1985. Commodities and capabilities. Amsterdam: NorthHolland.

Shear, M., A. Goodnough, S. Kaplan, et al. 2020. The lost month: How a failure to test blinded the U.S. to COVID-19. The New York Times, March 28. https://www.nytimes.com/2020/03 /28/us/testing-coronavirus-pandemic.html.
Sommer, L. 2020. Why the warning that coronavirus was on the move in U.S. cities came so late. National Public Radio, April 24, 2020. https://www.npr.org/sections/healthshots/2020/04/24/842025982/why-the-warning-thatcoronavirus-was-on-the-move-in-u-s-cities-came-so-late.

Svoboda, T., B. Henry, L. Shulman, et al. 2004. Public health measures to control the spread of the severe acute respiratory syndrome during the outbreak in Toronto. The New England Journal of Medicine 350(23): 2352-2361.

Thunstrom, L., S. Newbold, D. Finnoff, M. Ashworth, and J. Shogren. 2020. The benefits and costs of using social distancing to flatten the curve for COVID-19. Journal of Benefit-Cost Analysis 11(2): 179-195.

World Health Organization (WHO). 2009. Response to measles outbreaks in measles mortality reduction settings. Geneva: World Health Organization. https://www.ncbi.nlm.nih. gov/books/NBK143956/.

World Health Organization (WHO). 2014. Infection prevention and control of epidemic- and pandemic- prone acute respiratory infections in health Care. Geneva: World Health Organization. https://apps.who.int/iris/bitstream/handle/10665/112656 /9789241507134_eng.pdf?sequence $=1$.

Worldometer. 2020. COVID-19 coronavirus pandemic. https://www.worldometers.info/coronavirus/.

Xu, Z., L. Shi, Y. Wang, J. Zhang et al. 2020. Pathological findings of COVID-19 associated with acute respiratory distress syndrome. Lancet Respiratory Medicine 8(4): 420-422.

Publisher's Note Springer Nature remains neutral with regard to jurisdictional claims in published maps and institutional affiliations. 